\title{
Comparative Study of Chemical Characteristics, Phytochemical Contents and Antioxidant Activity of Polar and Non-polar Solvent Extracted Flaxseed Oil
}

\author{
Satarupa Ghosh', D.K. Bhattacharyya ${ }^{1 *}$, M. Ghosh ${ }^{1}$ \\ 1 Indian Institute of Engineering Science and Technology, School of Community Science and Technology, Howrah, India
}

\begin{abstract}
This study investigated the chemical characteristics and antioxidant activity of flax seed oil extracted by polar (isopropanol) and non-polar (hexane) solvent. The fatty acid profiles of the extracted oils were determined by Gas Chromatography. Flax seed oil was found to contain high level of linolenic acid around (57\%), followed by oleic acid (18\%) and linoleic acid (19\%), while the saturated acids were palmitic acid (6\%) and stearic acid (4\%). Analytical values such as acid value, peroxide value, iodine number, saponification value were determined and total phenolic and flavonoid content were performed. The antioxidant activity of flax seed oil extracted by polar and non-polar solvent, based on the determination of DPPH Free radical scavenging activity, FRAP assay, ABTS assay was evaluated.
\end{abstract}

Keywords: Flaxseed, chemical characteristics, phytochemical, antioxidant, activity.

\section{INTRODUCTION}

Flax seed (Linum usitatissimum) is used as a food source for having many valuable nutrients ${ }^{1}$. It contains near about $45 \%$ oil, $30 \%$ dietary fiber and $25 \%$ protein. The oil is rich in essential fatty acids mainly omega 3 fatty acid, which is higher than any other vegetable oils ${ }^{2}$, vitamin and minerals. Around $73 \%$ of the fatty acids in flaxseed are PUFA. Approximately $50 \%$ of the total fatty acid consists of $\alpha$-Linolenic acid (ALA) 3 . The $\alpha$-Linolenic acid and related chemicals in flaxseed oil seem to decrease inflammation. That is why flaxseed oil is thought to be useful for rheumatoid arthritis and other inflammatory

*Corresponding Author: D. K. Bhattacharyya, e-mail: dkb_oiltech@yahoo.co.in 
(swelling) diseases. Flaxseed is also a rich source of lignan component such as secoisolariciresinol di glucoside (SDG). SDG is known for its high antioxidant activity, and also for anticarcinogenic and phytoestrogenic properties ${ }^{4}$. Clinical and large-scale population studies show that flax improves laxation, lowers blood cholesterol, aids in blood glucose control, and blocks inflammation $^{5}$. There has been a growing interest for the probiotic properties of flaxseed and its beneficial effects in coronary heart disease, some kinds of cancer, neurological and hormonal disorders ${ }^{6}$. Mainly flaxseeds are produced in Canada, Argentina, U.S.A, China, India and Europe ${ }^{7}$. Flaxseed oil also has various industrial applications like linoleum and paints manufacture and in preserving wood and concrete ${ }^{8}$. Flaxseed oil is normally extracted by cold pressing ${ }^{9}$ and also by a combination of pressing and solvent extraction for almost complete recovery of flaxseed oil ${ }^{10}$. The use of bio renewable solvents like super critical $\mathrm{CO}_{2}$, ethanol, acetone, isopropanol and water has been gaining interest for extraction of vegetable oils. The use of polar and non-polar solvent may indicate significant difference in both content and properties (physical and chemical).

The aim of the study is to examine the chemical characteristics, phytochemical content and antioxidant activity of polar and non-polar solvent extracted flaxseed oil.

\section{METHODOLOGY}

\section{Sample and Chemicals}

Flaxseed was bought from local market of Sealdah, Kolkata (West Bengal, India). All chemicals were purchased from MERCK, INDIA.

\section{Oil Extraction}

To obtain oil by solvent extraction method, flaxseed powder of known weight was extracted with polar (iso propanol) and non-polar (hexane) solvents separately using Soxhlet apparatus (Borocil) for 5 hours on a steam bath at 70 -degree Celsius temperature. After extraction the remaining solvent was evaporated by rotary evaporator (BUCHI).

\section{Analytical Characteristics of Flaxseed Oil}

Acid value, peroxide value, saponification value and iodine value of flaxseed oil extracted by both polar and non-polar solvents were estimated according to the AOAC official method. 


\section{Phytochemical Content of Flaxseed Oil}

\section{Total Phenolic Content}

Total Phenolic content was determined spectrophotometrically using FolinCiocalteu reagent ${ }^{11}$. A calibration curve of gallic acid was prepared and the results were expressed as gallic acid equivalents (mg GAE/gm). An aliquot of the extract $(100 \mu \mathrm{l})$ was mixed with $250 \mu \mathrm{l}$ of Folin Ciocalteu's reagent and incubated in room temperature for 5 minutes. Then $1.5 \mathrm{ml}$ of $20 \%$ sodium bi carbonate was added to the mixture and the absorbance was measured at $765 \mathrm{~nm}$., against a blank, which was composed of the same reagents except test extract. A calibration curve of gallic acid was prepared and the results were expressed as gallic acid equivalents (mg GAE/100 $\mathrm{ml}$ ) and were calculated by the formula:

$\mathrm{T}=(\mathrm{C} \times V) / \mathrm{M}$ Where, $\mathrm{T}=$ Total content of phenolic compounds, milligram per gram dry weight of plant extract, in GAE; $\mathrm{C}=$ the concentration of gallic Acid established from the calibration curve, milligram per milliliter; $\mathrm{V}=$ the volume of extract, milliliter; $\mathrm{M}=$ the weight of plant extract, gram.

\section{Total Flavonoid Content}

The total flavonoids content was measured using the aluminium chloride colorimetric method ${ }^{12}$. The sample extract (250 $\mu$ l) was added to $4.5 \mathrm{ml}$ distilled water followed by $5 \% \mathrm{NaNO}_{2}(.03 \mathrm{ml})$. After incubation for 5 minutes $\mathrm{AlCl}_{3}$ (0.03 $\mathrm{ml}, 10 \%$ ) was added at $25^{\circ} \mathrm{C}$. The reaction mixture was treated with $2 \mathrm{ml}$ of $1 \mathrm{M} \mathrm{NaOH}$. The reaction mixture was then diluted to $10 \mathrm{ml}$ distilled water and absorbance was measured at $510 \mathrm{~nm}$ against a blank which was composed of the same reagents except the test extract. A calibration curve of catechin was prepared and the results were expressed as catechin equivalents ( $\mu \mathrm{g} \mathrm{CE} / 100$ $\mathrm{ml}$ ) and were calculated by the formula:

$\mathrm{T}=(\mathrm{C} \times V) / \mathrm{M}$ Where; $\mathrm{T}=$ total content of flavonoid compounds, mg per gram dry weight of plant extract, in Catechin equivalent, $\mathrm{C}=$ concentration of Quercetin established from the calibration curve in $\mathrm{mg} / \mathrm{ml}, \mathrm{V}=$ volume of extract in $\mathrm{ml}$ and $\mathrm{M}=$ weight of plant extract in gram.

\section{Fatty Acids Profiles}

The fatty acids composition of flaxseed oil was analyzed by Gas Chromatography (Agilent technologies, Model NO-7890B) after converting the fatty acids of the oil into their methyl esters according to AOCS official method Ce 2-66. Here DB-Wax capillary column (30 mL, 0.25 mm I.D., 0.25 $\mu \mathrm{m}$ F.T.) and FID (Flame Ionization detector) were used. The carrier gas was nitrogen, at a flow rate of $1 \mathrm{ml} /$ minute. Injector and detector temperatures were $200^{\circ} \mathrm{C}$ and $240^{\circ}$ 
$\mathrm{C}$ respectively. Column temperature was maintained from $150^{\circ} \mathrm{C}$ to $240^{\circ} \mathrm{C}$. Samples of $1 \mu \mathrm{l}$ were injected by manually, in the split mode.

\section{Antioxidant Activity}

Antioxidant activity of the flaxseed oil was measured by the following standard assay methods:

\section{DPPH Free radical scavenging activity assay}

The oil was assessed using 1, 1-diphenyl 2-picryl hydrazyl (DPPH) radical scavenging assay ${ }^{13}$. o.1mM solution of DPPH in methanol was prepared. An aliquot of .2 $\mathrm{ml}$ of sample was added to $2.8 \mathrm{ml}$ of this solution and kept in the dark place for 30 minutes. The absorbance was measured at $517 \mathrm{~nm}$. The ability to scavenge the DPPH radical was calculated with the following equation.

Inhibition percentage $(\mathrm{I} \%)=\left(\mathrm{A}_{\mathrm{o}}-\mathrm{A}_{1}\right) / \mathrm{A}_{0}$

( $A_{0}=$ Absorbance of the control, $A_{1}=$ Absorbance of the sample.)

\section{Ferric reducing antioxidant power (FRAP)}

The FRAP assay of the test samples were determined ${ }^{14}$. The FRAP reagent consists of $10 \mathrm{mM}$ 2,4,6-Tripyridyl-s-triazine (TPTZ) in $40 \mathrm{mM} \mathrm{HCL}, 250 \mathrm{mM}$ sodium acetate buffer ( $\mathrm{pH}-3.6)$ and $20 \mathrm{mM} \mathrm{FeCl}_{3}$. The reagent was freshly prepared by mixing 2,4,6-Tripyridyl-s-triazine (TPTZ) solution, $\mathrm{FeCl}_{3}, 6 \mathrm{H}_{2} \mathrm{O}$ solution and acetate buffer in a ratio of 1:1:10. An extract solution $(100 \mu \mathrm{l})$ was mixed with $900 \mu \mathrm{l}$ of FRAP reagent. The mixture was incubated at $37^{\circ} \mathrm{C}$ for 4 minutes and the absorbance was measured at $593 \mathrm{~nm}$.

\section{2,2'-azino-bis(3-ethylbenzothiazoline-6-sulphonic acid) (ABTS) Free radical scavenging activity}

2,2'-azino-bis(3-ethylbenzothiazoline-6-sulphonic acid) (ABTS) assay of flax seed oil was measured using the following method ${ }^{15}$. A solution of 2,2'-azinobis(3-ethylbenzothiazoline-6-sulphonic acid) (ABTS) $(7 \mu \mathrm{M})$ was prepared in distilled water and mixed with the solution of potassium per sulphate (2.45 $\mu \mathrm{M})$.The mixture was kept in the dark place for 16 hours at room temperature. The resulting intense color matches the 2,2'-azino-bis(3-ethylbenzothiazoline-6-sulphonic acid) (ABTS) radical cations. The solution was obtained subsequently diluted with distilled water and absorbance was measured at 734 $\mathrm{nm} .1 \mathrm{ml}$ of ABTS diluted solution was mixed with $10 \mu \mathrm{l}$ of sample at different concentration and the reaction mixture was kept for 6 minutes before measuring the absorbance. 2,2'-azino-bis(3-ethylbenzothiazoline-6-sulphonic acid) (ABTS) scavenging activity was calculated by the following equation. 
Inhibition Percentage $(\mathrm{I} \%)=\left(1-\mathrm{A} / \mathrm{A}_{\mathrm{o}}\right) \times 100$.

( $A=$ Absorbance of the sample. $A_{0}=$ Absorbance of the ABTS solution.)

\section{Statistical Analysis}

Results were expressed as mean value \pm standard deviation of three replications. Statistical differences were analyzed using one-way ANOVA followed by post-hoc Tukey HSD (Honestly Significant Difference) at level $\mathrm{p} \leq 0.05$.

\section{RESULTS AND DISCUSSION}

\section{Oil Extraction}

Many polar and non-polar solvents can be used to extract oil from oil seeds including flaxseed. In this study iso-propanol, a biorenewable solvent which is also food grade, was used as a polar solvent and n- hexane was used as a non-polar solvent. As much as $35 \%(\mathrm{w} / \mathrm{w})$ of flaxseed oil was extracted by isopropanol (polar solvent) while 40\% (w/w) flaxseed oil was obtained by hexane (non-polar solvent). Table 1 shows the respective oil yield in percentage by weight of seeds with polar and non-polar solvents. The less yield of flaxseed oil with iso propanol compared to n-hexane was due to the effect of water content of the seed .It could be that water became gradually miscible with iso propanol and reduced the solubility of the oil in iso propanol and ultimately extracting less amount of oil.On the other hand,oil seeds with as much as $14 \%$ water can be almost wholly extracted with $n$-hexane ${ }^{16,17}$. Generally flaxseed oil of good quality for food and pharmaceutical uses is produced commercially by cold pressing process with single pressing as flaxseed as flaxseed contains fairly high percentage of oil.Because of the importance of this oil from nutrition and health views the oil is not extracted by solvent process.However the soaring price of flaxseed oil and other edible oils demands for maximum recovery by extraction with organic food grade solvents.Infact, both polar and non-polar solvents are in use or can be used in extracting vegetable oils.

Table 1. Oil content in flaxseed as extracted by polar and non-polar solvents

\begin{tabular}{|l|l|}
\hline Solvent & Oil Content (\% w/w) \\
\hline Polar solvent (iso propanol) & $35 \% \pm 0.79$ \\
\hline Non-polar solvent (hexane) & $40 \% \pm 0.92$ \\
\hline
\end{tabular}

Correlation is significant at the $p \leq .05$ level. 


\section{Analytical Characteristics of Flaxseed Oil}

The analytical characteristics such as acid value, peroxide value, iodine number and saponification value of flaxseed oil extracted by polar and non-polar solvent were determined and included in the Table 2.

Table 2. Analytical Characteristics of Flaxseed oil

\begin{tabular}{|l|l|l|}
\hline Test & Polar solvent extracted oil & Nonpolar solvent extracted oil \\
\hline Acid value & $0.80 \pm 0.25 \mathrm{mg} \mathrm{KOH} / \mathrm{gm}$ oil & $0.84 \pm 0.14 \mathrm{mg} \mathrm{KOH} / \mathrm{gm}$ oil \\
\hline Peroxide value & $0.95 \pm 0.19 \mathrm{meq} / \mathrm{kg}$ oil & $0.99 \pm 0.21 \mathrm{meq} / \mathrm{kg}$ oil \\
\hline Iodine number & $172 \pm 0.98 \mathrm{iodine} / \mathrm{kg}$ oil & $180 \pm 0.79 \mathrm{iodine} / \mathrm{kg}$ oil \\
\hline Saponification value & $180 \pm 0.87 \mathrm{KOH} / \mathrm{gm}$ oil & $192 \pm 0.91 \mathrm{KOH} / \mathrm{gm}$ oil \\
\hline
\end{tabular}

Correlation is significant at the $p \leq .05$ level.

Acid value, peroxide value, iodine number, saponification value of flax seed oil extracted by the polar solvent had acid value $0.80 \mathrm{mg} \mathrm{KOH} / \mathrm{g}$ oil, peroxide value $0.95 \mathrm{meq} / \mathrm{kg}$ oil,iodine value $172 \mathrm{~g}$ iodine $/ 100 \mathrm{~g}$ oil and saponification value $180 \mathrm{mg} \mathrm{KOH} / \mathrm{g}$ oil , where as acid value, peroxide value, iodine number and saponification value of flax seed oil extracted by the non-polar solvent were $0.84 \mathrm{mg} \mathrm{KOH} / \mathrm{g}$ oil, $0.99 \mathrm{meq} / \mathrm{kg}$ oil, 180 g iodine $/ 100$ gm oil and192 mg $\mathrm{KOH} / \mathrm{g}$ oil respectively.

\section{Phytochemical Content}

The phytochemical analysis revealed the presence and content of phenolics and flavonoids content shown in Table 3. Phenolics, main secondary metabolite of plant origin. They have multiple biological effects including antioxidant properties. They are not only essential for plant growth but also produced as a response against injury of plant from pathogens.

Table 3. Phytochemical Content of Flaxseed oil

\begin{tabular}{|l|l|l|}
\hline Phytochemical Content & Polar solvent extracted oil & Nonpolar solvent extracted oil \\
\hline Total phenolic content & $1975 \pm 1.11 \mathrm{mg} \mathrm{GAE} / 100^{\mathrm{a}} \mathrm{gm}$ & $2120 \pm 1.07 \mathrm{mg} \mathrm{GAE} / 100^{\mathrm{a}} \mathrm{gm}$ \\
\hline Total flavonoid content & $402 \pm 0.95^{\mathrm{b}} \mu \mathrm{g} \mathrm{CE} / \mathrm{mg} \mathrm{sample}$ & $441 \pm 0.87^{\mathrm{c}} \mu \mathrm{g} \mathrm{CE} / \mathrm{mg}$ sample \\
\hline
\end{tabular}

The data are presented as mean value \pm standard deviation of triplet analyses. Different letters in the same column indicate statistically significant values ( $p \leq .05)$

Flavonoids are important for normal growth and development of plant and they give protection from infection and injury. It also contains anti cancer, anti allergic, anti inflammatory and anti microbial properties. 
Phenolic content of flaxseed oil obtained by polar and non-polar solvent extraction were $1975 \mathrm{mg}$ GAE/100 ml sample and $2120 \mathrm{mg} \mathrm{GAE} / 100 \mathrm{ml}$ sample respectively and total flavonoids content in the non-polar extracted flaxseed oil were $402 \mu \mathrm{g} \mathrm{CE} / 100 \mathrm{ml}$ sample and $441 \mu \mathrm{g} \mathrm{CE} / 100 \mathrm{ml}$ sample. From the above result, it can be stated that the analytical characteristics are nearly same for both polar and non-polar solvent extracted flax seed oil. However, the phytochemical content of flaxseed oil extracted by non-polar solvent was more than polar solvent extracted flaxseed oil.

\section{Fatty acid profile}

The fatty acid composition of flaxseed oil extracted by polar and non-polar solvent was presented in Table 4. There were five fatty acids found in the profile including palmitic acid(C16:0), stearic acid (C18:0),oleic acid (C18:0), linoleic acid (C18:2) and linolenic acid(C18:3). The major saturated fatty acids found in the flaxseed oil whether extracted by polar and non-polar solvent were palmitic acid (C16:0), stearic acid (C18:0),oleic acid (C18:1) with the concentration of 6.58\%-6.97\%, $4.39 \%-4.43 \%$ and $18.53 \%-18.51 \%$ respectively.Poly unsaturated fatty acids found in both polar and non-polar solvent extracted flaxseed oil were linoleic acid (C18:2) at 19.78 -19.82 \% and linolenic acid (C18:3) and $53.29-57 \cdot 35 \%$ respectively.

Table 4. Fatty acids Composition of Flaxseed Oil

\begin{tabular}{|l|l|l|}
\hline Fatty acids & Polar solvent & Non-polar solvent \\
\hline Palmitic acid (C16: 0) & $6.58 \%$ & $6.97 \%$ \\
\hline Stearic acid (C18:0) & $4.39 \%$ & $4.43 \%$ \\
\hline Oleic acid (C18:1) & $18.53 \%$ & $18.51 \%$ \\
\hline Linoleic acid (C18:2) & $19.78 \%$ & $19.89 \%$ \\
\hline Linolenic acid (C18:3) & $53.29 \%$ & $57.35 \%$ \\
\hline
\end{tabular}

\section{Antioxidant Activity}

The antioxidant activity of flaxseed oil samples was evaluated using DPPH, FRAP, ABTS assay and the results are shown in the Table 5. DPPH value of the non-polar solvent extracted flaxseed oil was slightly higher compared to the polar solvent extracted flax seed oil. FRAP value and ABTS value were near about same for flaxseed oil when extracted by both polar and non-polar solvent. 
Table 5. Antioxidant Activity of Flaxseed Oil

\begin{tabular}{|l|l|l|}
\hline Test & Polar solvent & Non-polar solvent \\
\hline DPPH & $80 \% \pm 0.34$ & $82 \% \pm 0.21$ \\
\hline FRAP $(\mu \mathrm{mol} / \mathrm{ml})$ & $10 \pm 0.03$ & $11 \pm 0.39$ \\
\hline ABTS & $43 \% \pm 0.52$ & $44 \% \pm 0.42$ \\
\hline
\end{tabular}

Correlation is significant at the $p \leq .05$ level.

Flaxseed oil could be extracted effectively and satisfactionaly by both polar and non-polar solvent. The polar solvent would be a better choice from nutritional and health or medicinal point of views.

The results of this study indicated that the chemical characteristics of both polar and non-polar solvent extracted flaxseed oils were nearly same. But the phytochemicals content and antioxidant activity appeared to be slightly more in case of the non-polar solvent extracted flaxseed oil compared to the polar solvent extracted flaxseed oil.

\section{ACKNOWLEDGEMENTS}

I would like to acknowledge my institute Indian Institute of Engineering Science and Technology (IIEST), Shibpur, Howrah, West Bengal, India for providing laboratory facilities. 


\section{REFERENCES}

1. Herchi, W.; Bahashwan, S.; Sebei, K.; Ben Seleh, H.; Kallel, H.; Boukhchina, S. Effects of germination on chemical composition and antioxidant activity of flaxseed (Linum usitatissimum L) oil. Grasas Aceites, 2015, 66, 1-8.

2. Herchi, W.; Arraez-Roman, D.; Trabelsi, H.; Bouali, I.; Boukhchina, S.; Kalle, H.; SeguraCarretero, A.; Fernandez-Gutierrez, A. Phenolic compounds in a flaxseed: A review of their properties and analytical methods. An overview of the last decade. J. Oleo. Sci. 2014, 63, 7-14.

3. Sebei, K.; Debez, A.; Herchi, W.; Boukhchina, S.; Kallel, H. Germination kinetics and seed reserve mobilization in two flax (Linum usitatissimum L.) cultivars under moderate salt stress. J Plant Biol. 2007, 5o, 447-454.

4.Touré, A.; Xueming, X. Flaxseed Lignans: Source, Biosynthesis, Metabolism, Antioxidant Activity, Bio-Active Components, and Health Benefits. Compr. Rev. Food. Sci. 2010, 9, 261269

5. Winnipeg, MB, Flax Council of Canada. Flax $-A$ Health and Nutrition Primer. 2oo3, 134 , 1806-1811.

6. Simopoulos, A.P. The importance of the ratio of omega-6/omega-3 essential fatty acids. Biomed. and Pharmacother. 2002, 56, 365-379.

7. Alander, J.; Lidefelt J. O. Vegetable oils and fats. Karlshamn: AB. 2002

8. Vaisey-Genser, M.; Morris, D. H. History of cultivation and uses of flaxseed. In Flax, the genus Linu m. Edited by: Muir A, Westscott N. Amsterdam: Hardwood Academic Publishers, 2001, 1-21.

9. Tanska, M.; Roszkowska, B.; Skrajda M.; Dabrowski, G. Commercial cold pressed flaxseed oils quality and oxidative stability at the beginning and end of their shelf life. JOleo Sci. 2016, 65, 111-121.

10. Kulkarni, N. G.; Kar, J, R.; Singhal, R. S. Extraction of Flaxseed Oil: A Comparative Study of Three-Phase Partitioning and Supercritical Carbon Dioxide Using Response Surface Methodology, Food Bioproc Tech. 2017, 10, 940-948.

11. McDonald, S.; Prenzler, P. D.; Antolovich, M.; Robards, K. Phenolic content and antioxidant activity of olive extract. Food Chem. 2001, 73, 73-84.

12. Chang, C.; Yang, M.; Wen, H.; Chern, J. Estimation of total flavonoid content in propolis by two complementary colorimetric methods. J. Food Drug. Anal. 2002, 10, 178-182.

13. Gorinstein, S.; Vargas, O. J. M.; Jaramillo, N. O.; Salas, I. A.; Ayala, A. L. M.; ArancibiaAvila, P.; Toledo, F.; Katrich, E.; Trakhtenberg, S. The total polyphenols and the antioxidant potentials of some selected cereals and pseudocereals. Eur. Food Res. and Technol. 2007, 225, 321-328.

14. Benzie, I.F.F.; Strain, J.J. The ferric reducing ability of plasma (FRAP) AS A MEASSURE OF "antioxidant power" the FRAP assay. Anal Biochem. 1996, 239, 70-76.

15. Ghosh, S.; Bhattacharya, D. K.; Ghosh, M. Study on proximate composition, phytochemical content, oxidative stability, antioxidant activity and fatty acid compositionof enzyme aided aqueous extraction of flax seed oil. ASNH, 2019, 3, 5-9.

16. Fan, H. P.; Morris, J. C.; Wakeham, H. Diffusion phenomena in solvent extraction of peanut oil: Effect of cellular structure. Ind. Eng. Chem. RES. 1948, 4O, 195-199.

17. Wingard, M. R.; Shand, W. C. The determination of the rate of extraction of crude lipids from oil seeds with solvents. J. Am. Oil Chem. Soc. 1949, 26, 422-426. 
18. Prescha, A.; Grajzer, M.; Dedyk, M.; Grajeta, H. The Antioxidant Activity and Oxidative Stability of Cold-Pressed oils. J. Am. Oil Chem. Soc. 2014, 91, 1291-1301.

19. AOAC International, Official methods of analysis of AOAC International,16th ed., Gaithersburg, 1999.

20. Litchfield, C. Analysis of Triglycerides, Academic Press, New York, 1972. pp: 17- 35.

21. Choo, W. S.; Birch, J.; Dufour J. P. Physico chemical and and quality characteristics of cold-pressed flax seed oils. J. Food Compos. Anal. 2007, 20, 202-211.

22. Gorinstein, S.; Cvikrova, M.; Machackova, I.; Haruenkit, R.; Park, Y. S.; Jung, S. T.; Yamamoto, K.; Ayala, A. L. M.; Katrich, E.; Trakhtenberg, S. Characterization of antioxidant compounds in Jaffa sweeties and white grape fruits. Food Chem. 2004, 84, 503-510.

23. El-Beltagi, H. S.; Salama, Z. A.; El-Hariri, D. M. Evaluation of fatty acids profile and the content of some secondary metabolites in seeds of different flax cultivars (Linum usitatissimum L.), Gen. Appl. Plant Physiol. 2007, 33, 187-202.

24. Gutfinger, T. Polyphenols in olive oils. J. Am. Oil Chem. Soc. 1981, 58, 966-968.

25. Silva, C.; Garcia, V. A. S.; Zanetle, C. M. Chia (Salvia hispanica L.) Oil extraction using different organic solvents:oil yield,fatty acids profile and technological analysis of defatted meal. Int Food Res. J. 2016, 23, 998-1004.

26. Mingyai, S.; Kettawan, A.; Srikaeo, K.; Singanusong, R. Physico chemical and antioxidant properties of rice bran oils produced from coloured rice using different extraction methods. $J$ Oleo sci. 2017, 66, 565-572.

27. Barthet, V. J.; Klensprof -Pawlik, D.; Przybylski, R. Antioxidant Activity of Flax seed meal components. Can. J. of Plant Sci. 2014, 94, 593-602.

28. Bouaziz, F.; Koubaa, M.; Barba, F. J.; Roohinejad, S.; Chaabouni, S. E. Antioxidant properties of water-soluble gum from flax seed hull, Antioxidants (Basel), 2016, 5, 1-10. 